\title{
Tourism Geographies, Tourist Studies and the Turn towards Mobilities
}

Kevin Hannam*

School of Arts, Design, Media and Culture, University of Sunderland

\begin{abstract}
Tourism is frequently acclaimed as one of the world's largest and most pervasive industries. Research into tourism has grown rapidly in recent years with many new books and journals appearing. In particular, this article notes that perhaps three new journals have marked the coming of age of tourism-related research, namely, Tourism Geographies, Tourist Studies and finally Mobilities. While a great deal of other research has been published in books and journals and indeed many other new tourism journals have been started, this article utilises the start of these journals as benchmarks for a theoretical engagement with tourism research. This article thus begins by reviewing research into tourism geographies and focuses on work that has examined destination branding in the face of globalising processes. The article goes on to review research that has been concerned primarily with host-guest interactions in terms of tourist studies. Indeed, both residents and tourist's performances have been the focus of much contemporary research particularly by researchers who have begun to view tourism as increasingly constitutive of everyday life rather than being simply an escape from it. Finally, it is argued that the concept of mobilities helps us to understand global tourism in the context of other social and spatial travel processes.
\end{abstract}

\section{Introduction}

There was a time when the study of tourism in geography [perhaps like that of transport in geography (Goetz 2006)] was only found on the margins of geographical knowledge in comparison with more established topics. Issues of movement in geography have arguably now taken centre stage though. However, while contemporary studies of tourism have grown rapidly, this has been largely through case study research that critiques aspects of tourism policies. See, for example, the extreme example of Horner and Swarbrooke's (2004) recent text International Cases in Tourism Management, and, of course, journal publications are literally littered with numerous other examples of empirical case studies. While such engagement with the practical consequences of tourism can be applauded and have their uses, it has also been increasingly recognised that more sophisticated theoretical analyses of tourism are needed. Indeed, Dann 
(1999, 27) has argued that 'unless issues are problematised - unless we acknowledge that our understanding is incomplete - we will never adequately address issues of tourism development.' Hence, we now find that a new body of tourism knowledge has emerged driven in part by researchers who have sought to re-situate tourism at the core of geographical study. On the one hand, this can be seen in recent issues of established journals such as Annals of Tourism Research and Tourism Management. On the other hand, the launch of new more theoretically orientated journals concerned with tourism practices, such as Tourism Geographies, (Lew 1999), Tourist Studies, (Franklin and Crang 2001), and Mobilities (Hannam et al. 2006) and new critical anthologies (Ateljevic et al. 2007; Lew et al. 2004) have demonstrated that research into tourism has begun to take on board theoretical issues that have been the mainstay of geography and other social sciences for some time. Moreover, the recent launch of more specialised tourism journals such as the Journal of Heritage Tourism (Timothy and Boyd 2006), the Journal of Tourism and Cultural Change (Robinson and Phipps 2003) and the Journal of Ecotourism (Fennell 2002), have reflected a renewed interest in the study of tourism as well, but these have also a tendency to revert to the case study syndrome.

However, from the perspective of the new journals mentioned at first, tourism is increasingly viewed not as an ephemeral aspect of social life that is practised outside normal, everyday life. Rather, it is seen as integral to wider processes of economic and political development processes and even constitutive of everyday life (Edensor 2007; Franklin 2003). Indeed, Franklin and Crang $(2001,3)$ point out that, 'tourism has broken away from its beginnings as a relatively minor and ephemeral ritual of modern national life to become a significant modality through which transnational modern life is organised.' This article thus reviews some of the recent engagements with theory in tourism research (largely) from a geographical perspective. Geographers have been interested in understanding aspects of the dialectic between the global and the local for a very long time; hence, this article begins by reviewing research into tourism destinations in the face of globalising processes - a core part of the new tourism geographies - before moving on to discuss work that has re-focused analysis upon host-guest interactions - tourist studies. Finally, the article examines the emerging mobilities 'paradigm' in order to demonstrate the importance that tourism has begun to take in our understandings of wider sociospatial processes. In particular, this article argues that, perhaps, three new journals have marked the coming of age of tourism-related research, namely, Tourism Geographies, Tourist Studies and finally Mobilities. While a great deal of other research has been published in other books and journals and indeed many other new tourism journals have been started (as cited in this article), this article utilises the start of these journals as benchmarks for a greater theoretical engagement within tourism research. 


\section{Tourism Geographies}

The journal Tourism Geographies (1999 to present) like the Journal of Sustainable Tourism [1992 to present (Bramwell and Lane 2007)] has focused partly on issues concerning tourism's environmental impacts and sustainability; however, an increasing concern of the former journal has been with issues to do with theoretical tourism destinations in the face of globalising pressures. Indeed, the analysis of tourism needs to take account of theoretical advances in the study of processes of globalisation in order to produce more sophisticated comparisons of both core and periphery experiences of the localisation of tourism development. As a result of globalising processes, virtually everyone now lives in a region that is subject to some form of tourism development and globalising processes have resulted in greater flexibility, hybridity and difference as various localities are restructured (Jackson 2004; Potter et al. 1999; Saarinen 2004).

As a consequence of such globalising and restructuring processes, many countries, regions and places have sought increasingly sophisticated means to actively brand and market, create and construct particular destinations for development (Morgan et al. 2002). Such methods of tourism promotion are of course 'grounded in relations of power, dominance, and subordination which characterize the global system' (Morgan and Pritchard 1998, 6). Moreover, in our global system, tourism marketing has become increasingly complex and is no longer concerned simply with representing or conveying an image of a place, but with attempting to sell an experience of a place by explicitly relating to the lifestyles of consumers. As an example, the regional development agency One NorthEast (ONE) in the North East of England recently developed its Passionate People, Passionate Places brand in response to the competitive global pressures and lifestyle changes (Figure 1).

In marketing terms, a brand is a unique combination of product characteristics and added values that have taken on a particular meaning in the minds of consumers: 'When consumers make brand choices about products - including destinations - they are making lifestyle statements since they are buying into not only an image but also an emotional relationship' (Morgan and Pritchard 2002, 12). From a geographical perspective, tourism destination brands are reaching beyond the tourism industry and are also now seen as integral to wider processes of economic development:

Many of those brands at the leading edge of destination marketing are seeking to position themselves as place brands, whereby whole countries, states and regions are embarking on brand building initiatives that are inclusive of tourism and economic development. (Morgan et al. 2002, 4)

Similarly, Morgan and Pritchard $(2002,39)$ argue that: 


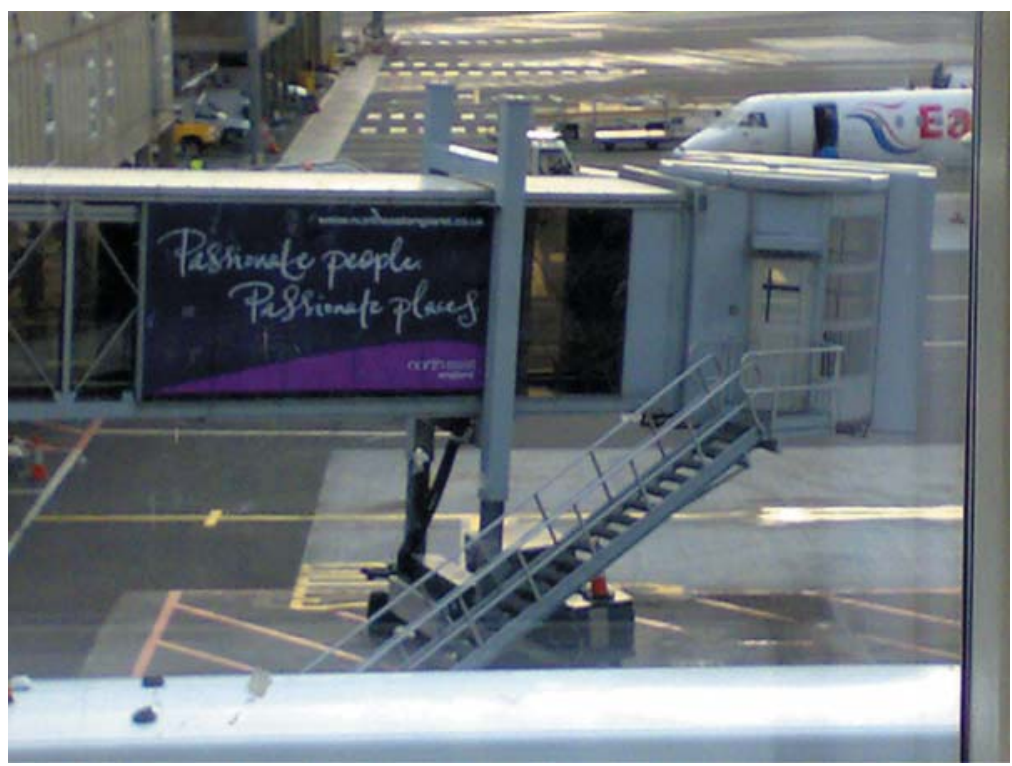

Fig. 1. Destination branding: Passionate People, Passionate Places at Newcastle International Airport.

[W]hile tourism is just one element of any destination's economy it should be integral to place marketing since it supports and leads the development of a place brand. The creation of celebrity and emotional appeal through a destination brand opens the way for other economic development-oriented agencies to communicate to would-be investors and residents.

Destination branding is viewed as perhaps the most powerful marketing weapon available to contemporary regional developers confronted by increasing global competition. Tourism destinations need to create unique identities and selling point(s) as the basis of survival in an increasingly competitive capitalist global tourism marketplace. In their overview, Morgan et al. (2002) argue that there are currently a number of key issues facing contemporary tourism marketing in order to develop a successful 'brand'. These are: the role of politics, the role of market research, the need to build partnerships and the role of brand 'champions' in driving brand development. In the aftermath of $9 / 11$ and various environmental crises, perhaps the former - (geo)politics - is the most pertinent currently as both global and domestic political changes can often unsettle or even thwart national and regional place branding strategies. However, unfortunately, there is a paucity of research into the role of geopolitics in current critical tourism research except for case studies by Saldanha (2002) and Worthington and Sedakat (2005) and the text by Timothy (2001) Tourism and Political Boundaries. 
Underpinning the analysis of tourism place branding, though, has been the case for a new economic stage of capitalist development: one of experiences as distinct from services. As Pine and Gilmore $(1999,2)$ explain:

When a person buys a service, he purchases a set of intangible activities carried out on his behalf. But when he buys an experience, he pays to spend time enjoying a series of memorable events that a company stages - as in a theatrical play - to engage him in a personal way.

Interestingly, Pine and Gilmore trace back the idea of an experience driven economy to the opening of that quintessential tourist attraction, Disneyland, in 1955. Tourism is also increasingly reliant on special events that draw visitors in for unique experiences. The corollary of the experience economy is the need for experiential marketing and Schmitt (1999) makes just this case. There is a focus on customer experiences, in terms of encountering or living through situations connected with the customer's own lifestyle. Experiences provide sensory, embodied, emotional, cognitive and relational values and there is a focus on the creation of synergies of meaning, consumption and loyalty. Perhaps the best exponent of this is Richard Branson's Virgin brand that integrates travel and tourism with other forms of everyday consumption: 'We have put the Virgin experience together across retailing, entertainment, food, music and travel ... (Richard Branson, cited in Schmitt 1999, 27).

Morgan and Pritchard (2002) argue that rather than the clichéd images of sand, sea and sun, or simply price, it is perhaps an embodied empathy with a destination that now persuades tourists to visit and re-visit a particular destination. Successful tourism marketing seeks to make an emotional attachment with the consumer's lifestyle by being credible, deliverable and sustainable. The development of such experiential relationships can be seen in tourism marketing campaigns aimed at Diaspora populations, for example. Recent marketing campaigns aimed at the Indian Diaspora have sought to engage second- and third-generation Indians who are now living outside to India to re-discover their roots. This has been done not just through the production images in the Incredible India brand but also through the organisation of specific events that bring the Diaspora population together for key experiences such as festivals (Hannam 2004b).

Crucially, in the contemporary world, such experiences are emphatically mediatised, too (Crouch et al. 2005). On one level, simple things like postcards and photographs are widely disseminated by tourists and they may be seen as personalised souvenirs for tourists and their friends and relatives (Markwell 1997; Tolia-Kelly 2004). And, films and television programmes are increasingly important in creating and maintaining the experiential, mediatised connections between destinations and tourism consumer experiences; while the Internet provides an immediate means of information and commercial transaction (Beeton 2005; Crouch et al. 
2005; Mordue 2001; Morgan et al. 2001; Tzanelli 2006, 2007; White and White 2007). All these media forms are an everyday part of the intertextuality of the contemporary experiential consumption of tourism destinations. In contemporary mediatised tourism destinations, the interaction between so-called 'hosts' and 'guests' is central and this has, by and large, become the focus of work published in the journal Tourist Studies, to which we now turn.

\section{Tourist Studies}

Early work on tourism consumption focused largely on the impacts of tourism - notably the 'guests' on the 'hosts' - the economic strains and cultural changes that have arisen through the growth in global tourism (Smith 1977). Since then such tourism research has become both more theoretically sophisticated and empirically focused with research on the impact of tourism on guests being replaced by an emphasis on researching tourists' behaviour, interactions and consumption in particular spaces and is seen in much of the work published in the journal Tourist Studies (2001 to present). Much of this research has been centred on notions of tourists' agency (see MacCannell 2001) and has in turn developed ideas concerned with the body in tourism. Indeed, the classic works by Jokinen and Veijola (1994) and Johnston (2001) had earlier made the important point that tourism frequently revolves around various hedonistic bodily experiences, from sunbathing to dancing and drinking. They suggested that motivations for travel may emerge from a desire to immerse the body in contexts that have only previously been experienced through visual representations. Two clear lines of research on the embodiment of tourism can be traced from this starting point.

First, recent work on the body in sex tourism is especially pertinent in this context (see, for example, Bauer and McKercher 2003; Bishop and Robinson 1997; Clift and Carter 2000; Law 2000; Ryan and Hall 2001). As Johnston $(2001,196)$ argues 'sexually embodying tourism challenges Western constructions of disembodied masculinist knowledge.' Second, the simple binary division of 'hosts' and 'guests' has also been called into question by researchers in the context of blurrings between migration practices and tourism (see Bell and Ward 2000; O'Reilly 2003; Potter 2005; Sherlock 2001; Williams and Hall 2002). Indeed, 'there are new forms of mobility which were unimaginable a generation earlier... the young Pole visiting Germany on a tourist visa, but paying for his or her trip by taking casual work and petty trading . . ' (Williams and Hall 2002, 2 ). And migrants frequently return home as tourists to visit friends and relatives while being ostensibly 'on holiday' in their country of origin (Coles and Timothy 2004; O'Reilly 2003). This has subsequently led to a more in depth discussion of the sensuous and embodied encounters of hosts and guests (Baerenholdt et al. 2004; Crouch et al. 2001; Crouch and 
Desforges 2003; Obrador Pons 2003). Moreover, much of the recent work on such topics as tourism and sex and tourism and migration has utilised the metaphor of performance in discussing such sensuous encounters.

Interest in the use of the metaphor of performance of tourism can be linked back, of course, to Dean MacCannell's (1999) early work on the tourist and staged authenticity. He drew upon Goffman's (1959) structural social division of front and back regions: 'The front is the meeting place of hosts and guests or customers and service persons, and the back is the place where members of the home team retire between performances to relax and to prepare' (MacCannell 1999, 92). Moreover, notions of the authentic in tourism have long been debated (and even haunted) in tourism research [see, for example, work the critical review by Wang (1999)].

Edensor (1998a, 47) again drawing upon Goffman, differentiated between notions of enclavic and heterogeneous tourist spaces in his use of the metaphor of performance, arguing that:

... [T] he production of enclavic tourist space is part of a wider process whereby space, particularly in the West, is becoming more regulated, commodified and privatised ... The imperatives of modernist planning and consumer capitalism have tended to transform space so that it maximises consumption and facilitates transit.

And he goes on to state that: "Above all the tourist enclave is designed for gazing. Theming imposes a visual order: a predictable spectacle of few surprises ...' (Edensor 1998a, 51). Needless to say tourists often feel frustrated in enclavic spaces. Examples, of such enclavic spaces of performance abound from scripted historical rituals (Chronis 2005; Crang 1996) to staged dramas in theme parks such as Disneyworld (Fjellman 1992) or even zoos (Beardsworth and Bryman 2001) and dramatised landscapes such as 'Braveheart country' (Edensor 1998b) or 'Heartbeat country' (Mordue 2001).

Heterogeneous tourist spaces meanwhile, '. . . are typified by more contingent and local forms of planning, regulation and surveillance. Rather than security guards, video surveillance and policing, local power-holders exercise policies of exclusion and control. Overall, however, surveillance is rather low level' (Edensor 1998a, 56). Edensor (1998a, 59) goes on to argue that:

The 'smellscapes' of heterogeneous tourist space are rich and varied. The jumbled mix of pungent aromas - sweet, sour, acrid and savoury - produces intense 'olfactory geographies'. Equally diverse is the soundscape which combines the noises generated by numerous human activities, animals, forms of transport and performed and recorded music, to produce a changing symphony of diverse pitches, volumes, rhythms and tones.

In terms of the embodied performance of tourism, Edensor (1998a, 62) argues that, '. . enclavic spaces are carefully staged and designed so that 
performance is somewhat prescriptive, whereas in heterogeneous spaces, stage boundaries are less clear and a wider range of improvisation is encouraged.' In his later work, Edensor (2001) goes on to suggest that in enclavic tourist spaces, various 'directors' and 'stage managers' (key tour personnel), as well as guidebooks carefully and cleverly choreograph tourists' movements. Nevertheless, while some post-tourists may actually revel in the artificiality and staging, others actively resist conformist performances or just improvise. On the other hand, heterogeneous tourist spaces, such as markets or bazaars, may 'provide stages where transitional identities may be performed alongside the everyday enactions of residents, passers-by and workers' (Edensor 2001, 64). Here, 'the sensory and social overload means that reflexive performances may be denied by the immanence of experience, and in any case rehearsed tourist roles have little coherence in these settings' (Edensor 2001, 77).

The everyday experience and performance of tourism though can also be viewed as a subtle form of resistance to the power-knowledge regimes laid down at various scales by states, non-governmental organisations, agents and guides (Edensor 2001). Warren (1998), for example, has examined the importance of the regional press in articulating resistance in her analysis of the control of resort development in Bali [see also Picard's (1996) more complete anthropological analysis of tourism in Bali here, too].

Sometimes, even the state itself may resist the global omnipotence of tourism development (Hannam 2004a). Moreover, in the spaces left open to them, hosts or locals can often be both proactive and resistant, as they negotiate and contest the direction of development (MacDonald 1997; Sheller and Urry 2004). For example, through tourism, local people often become more aware of their own localities and voice this in their own words and symbols (Mordue 1999). As Oakes $(1999,128)$ contends 'the broader conceptual point is that tourism development must be viewed, in part, as a story told by locals about themselves.' Similarly, Quinn's (2007, 459) recent research with Venetian residents argues that hosts are not simply passive subjects acted upon in tourism contexts: "populations who share their places with tourists are active in reconfiguring practices, relationships, and mobilities with and within places' [see also the more thorough historical and anthropological research on tourism in Venice by Davis and Marvin (2004)].

\section{Mobilities}

Developing further the notion of performance (and performativities) in tourism and integrating it with geographical and sociological research into transport and communications, Sheller and Urry $(2006,1)$ go as far as to argue that: 'It seems that a new paradigm is being formed within the social sciences, the "new mobilities" paradigm.' Broadly, they argue that the concept of mobilities is concerned with mapping both the large-scale 
movements of people, objects, capital and information across the world, as well as the more local processes of daily transportation, movement through public space and the travel of material things within everyday life. From a mobilities perspective, the notion of just tourism per se is now perhaps arguably rather obsolete:

Mobilities of people and objects, airplanes and suitcases, plants and animals, images and brands, data systems and satellites, all go into 'doing' tourism. Tourism is also concerned with the relational mobilizations of memories and performances, gendered and racialized bodies, emotions and atmospheres. (Sheller and Urry 2004, 1)

Again, tourism and more importantly travel is increasingly seen as a process that has become integral to social life. It is not just about the purchase of second homes and the interconnections between tourism and migration. Rather, every thing seems to be in perpetual movement throughout the world. Most people travel - academics, terrorists, tourists, military people, business people, homeless people, celebrities, migrants, refugees, backpackers, commuters, students, friends - filling the world's planes, trains, ships, buses, cars and streets. In the contemporary world, all sorts of political, technological, financial and transportational changes have been critical in significantly lowering the mobility barriers for many. Tourism, leisure, transport, business, travel, migration and communication are thus all blurred and need to be analysed together in their fluid interdependence rather than discretely (Hannam et al. 2006; Sheller and Urry 2006).

However, new technologies enhance the mobility of some peoples and places and heighten the immobility of others, especially as they try to cross borders (Amoore 2006; Sheller and Urry 2006; Timothy 2001; Verstraete 2004). Mobilities are thus caught up in power geometries of everyday life (Massey 1994). As Tesfahuney (1998, 501) writes: 'Differential mobility empowerments reflect structures and hierarchies of power and position by race, gender, age and class, ranging from the local to the global.' Recent human and environmental disasters such as global health scares, multiple suicide bombings, and extreme weather events such as hurricanes, tsunamis and so on, engender their own unique differential mobilities and immobilities (Hannam et al. 2006).

On the one hand, moving between places physically or virtually can be a source of status and power for some tourists such as backpackers (see Hannam and Ateljevic 2007; Richards and Wilson 2004). On the other hand, where mobilities are coerced it can generate deprivation as with many migrants and refugees around the world (see Indra 1998; Kofman 2002) or forced re-settlement schemes for tribal populations in the face of tourism mobilities (see Hannam 2005). Such mobilities and immobilities become particularly apparent in so-called tourism 'contact zones' at the interstices of different countries where notions of citizenship can become 
highly contested and multiple identities become increasingly fluid (see Bianchi 2000; Sparke 2006). Analysing contemporary mobilities thus involves examining many consequences for different peoples and different places located in the fast and slow lanes of societies (Hannam et al. 2006; Sheller and Urry 2006).

Sheller and Urry (2006) go on to discuss how new forms of virtual and imaginative travel are also emerging, and are being combined in unexpected ways with physical travel. The analysis of mobilities thus also includes movements of images and information on local, national and global media. Hannam et al. (2006) argue that studies of tourism need to be brought together with more local concerns about everyday transportation, material cultures and spatial relations of mobility and immobility, as well as with more technological concerns about mobile information and communication technologies and emerging infrastructures of security and surveillance (on the latter, see Adey 2006).

\section{Conclusion}

Understandings of power relations, the use of the metaphor of performance and the development of the concept of mobilities all emphasise that our understanding of tourism and leisure practices need to be located in broader social contexts. As Sheller and Urry $(2006,17)$ argue, bringing it all together: 'Places are thus not so much fixed but are implicated within complex networks by which hosts, guests, buildings, objects and machines are contingently brought together to produce certain performances in certain places at certain times.' In the context of globalising processes, research into travel and tourism arguably now seem to be taking centre stage. Giving the differential access to forms of mobilities though, we need to continue to question what the mobility empowerments are for hosts and guests in the contemporary world and what their impacts are on the mobilities of others.

\section{Short Biography}

Professor Kevin Hannam has a $\mathrm{PhD}$ in geography from the University of Portsmouth, Hampshire, UK. He is Professor of Tourism Development at the University of Sunderland and has published widely on tourism issues. He is co-editor with Mimi Sheller and John Urry of the journal Mobilities.

\section{Note}

^ Correspondence address: Kevin Hannam, School of Arts, Design, Media and Culture, University of Sunderland, Priestman Building, Green Terrace, Sunderland SR1 3PZ, UK. E-mail: kevin.hannam@sunderland.ac.uk. 


\section{References}

Adey, P. (2006). If mobility is everything then it is nothing: towards a relational politics of (im)mobilities. Mobilities 1 (1), pp. 75-94.

Amoore, L. (2006). Biometric borders: governing mobilities in the war on terror. Political Geography 25, pp. 336-351.

Ateljevic, I., Pritchard, A., and Morgan, N. (eds) (2007). The critical turn in tourism studies. Amsterdam, The Netherlands: Elsevier.

Baerenholdt, J., et al. (2004). Performing tourism places. Aldershot, UK: Ashgate.

Bauer, T., and McKercher, B. (eds) (2003). Sex and tourism: journeys of romance, love and lust. Binghamton, NY: Haworth Press.

Beardsworth, A., and Bryman, A. (2001). The wild animal in late modernity: the case of the disneyization of zoos. Tourist Studies 1 (1), pp. 83-104.

Beeton, S. (2005). Film-induced tourism. Clevedon, UK: Channel View.

Bell, M., and Ward, G. (2000). Comparing temporary mobility with permanent migration. Tourism Geographies 2 (1), pp. 87-107.

Bianchi, R. (2000). Migrant tourist workers: exploring the contact zones of post-industrial tourism. Current Issues in Tourism 3 (2), pp. 107-137.

Bishop, R., and Robinson, L. (1997). Night market: sexual cultures and the Thai economic miracle. London: Routledge.

Bramwell, B., and Lane, B. (2007). Audiences and languages for sustainable tourism research. Journal of Sustainable Tourism 15 (1), pp. 1-4.

Chronis, A. (2005). Coconstructing heritage at the Gettysburg storyscape. Annals of Tourism Research 32 (2), pp. 386-406.

Clift, S., and Carter, S. (eds) (2000). Tourism and sex: culture, commerce and coercion. London: Pinter.

Coles, T., and Timothy, D. (eds) (2004). Tourism, diasporas and space. London: Routledge.

Crang, M. (1996). Magic kingdom or a quixotic quest for authenticity? Annals of Tourism Research 23 (2), pp. 415-431.

Crouch, D. (1999). Introduction: encounters in leisure/tourism. In: Crouch, D. (ed.) Leisure/ tourism geographies: practices and geographical knowledge. London: Routledge, pp. 1-16.

Crouch, D., and Desforges, L. (2003). The sensuous in the tourist encounter. Tourist Studies 3 (1), pp. 5-22.

Crouch, D., Aronsson, L., and Wahlstrom, L. (2001). Tourist encounters. Tourist Studies 1 (3), pp. 252-270.

Crouch, D., Thompson, F., and Jackson, R. (eds) (2005). The media and the tourist imagination. London: Routledge.

Dann, G. (1999). Theoretical issues for tourism's future development: identifying the agenda. In: Pearce, D. and Butler, R. (eds) Contemporary issues in tourism development. London: Routledge, pp. 13-30.

Davis, R., and Marvin, G. (2004). Venice the tourist maze: a cultural critique of the world's most touristed city. Berkeley, CA: University of California Press.

Edensor, T. (1998a). Tourists at the Taj: performance and meaning at a symbolic site. London: Routledge.

—. (1998b). Reading braveheart: representing and contesting Scottish identity. Scottish Affairs 21, pp. 135-158.

- (2001). Performing tourism, staging tourism: (re)producing tourist space and practice. Tourist Studies 1 (1), pp. 59-81.

- (2007). Mundane mobilties, performances and spaces of tourism. Social \& Cultural Geography 8 (2), pp. 199-215.

Fennell, D. (2002). Ecotourism: where we've been; where we're going. Journal of Ecotourism 1 (1), pp. $1-6$.

Fjellman, S. (1992). Vinyl leaves: Walt Disney World and America. Boulder, CO: Westview.

Franklin, A. (2003). Tourism: an introduction. London: Sage.

Franklin, A., and Crang, M. (2001). The trouble with tourism and travel theory? Tourist Studies 1 (1), pp. 5-22. 
Goetz, A. (2006). Transport geography: reflecting on a subdiscipline and identifying future research trajectories. Journal of Transport Geography 14 (3), pp. 230-231.

Goffman, E. (1959). The presentation of self in everyday life. Harmondsworth, UK: Penguin.

Hannam, K. (2004a). Tourism and forest management in India: the role of the state in limiting tourism development. Tourism Geographies 6 (3), pp. 331-351.

- (2004b). India and the ambivalences of diaspora tourism. In: Coles, T. and Timothy, D. (eds) Tourism, diasporas and space: travels to promised lands. London: Routledge, pp. 246-260.

- (2005). Tourism management issues in India's National Parks. Current Issues in Tourism $8(2 / 3)$, pp. $165-180$.

Hannam, K., and Ateljevic, I. (eds) (2007). Backpacker tourism. Clevedon, UK: Channel View.

Hannam, K., Sheller, M., and Urry, J. (2006). Editorial: mobilities, immobilities and moorings. Mobilities 1 (1), pp. 1-22.

Horner, S., and Swarbrooke, J. (2004). International cases in tourism management. Oxford, UK: Elsevier.

Indra, D. (ed.) (1998). Engendering forced migration. Oxford, UK: Berghahn.

Jackson, P. (2004). Local consumption cultures in a globalizing world. Transactions of the Institute of British Geographers 29, pp. 165-178.

Johnston, L. (2001). (Other) bodies and tourism studies. Annals of Tourism Research 28 (1), pp. 180-201.

Jokinen, E., and Veijola, S. (1994). The body in tourism. Theory, Culture \& Society 11 (3) pp. 125-151.

Kofman, E. (2002). Contemporary European migrations, civic stratification and citizenship. Political Geography 21, pp. 1035-1054.

Law, L. (2000). Sex work in Southeast Asia: the place of desire in a time of AIDS. London: Routledge.

Lew, A. (1999). Editorial: A place called tourism geographies. Tourism Geographies 1 (1), pp. 1-2.

Lew, A., Hall, C., and Williams, A. (eds) (2004). A companion to tourism. Oxford, UK: Blackwell.

MacCannell, D. (1999). The tourist: a new theory of the leisure class. Berkeley, CA: University of California Press.

- (2001). Tourist agency. Tourist Studies 1 (1), pp. 23-37.

MacDonald, S. (1997). A people's story: heritage, identity and authenticity. In: Rojek, C. and Urry, J. (eds) Touring cultures. London: Routledge, pp. 155-175.

Markwell, K. (1997). Dimensions of photography in a nature-based tour. Annals of Tourism Research 24 (1), pp. 131-155.

Massey, D. (1994). Power-geometry and a progressive sense of place. In: Robertson, G., et al. (eds) Mapping the futures. London: Routledge, pp. 59-69.

Mordue, T. (1999). Heartbeat country: conflicting values, coinciding visions. Environment and Planning A 31, pp. 629-646.

- (2001). Performing and directing resident/tourist cultures in heartbeat country. Tourist Studies 1 (3), pp. 233-252.

Morgan, N., and Pritchard, A. (1998). Tourism, promotion and power: creating images, creating identities. Chichester, UK: Wiley.

- (2002). Contextualising destination branding. In: Morgan, N., Pritchard, A. and Pride, R. (eds) Destination branding: creating the unique destination proposition. Oxford, UK: ButterworthHeinemann, pp. 124-147.

Morgan, N., Pritchard, A., and Pride, R. (eds) (2002). Destination branding: creating the unique destination proposition. Oxford, UK: Butterworth-Heinemann.

Morgan, N., Pritchard, A., and Abbot, S. (2001). Consumers, travel and technology: a bright future for the web or television shopping? Journal of Vacation Marketing 7 (2), pp. 110-124.

O'Reilly, K. (2003). When is a tourist? The articulation of tourism and migration in Spain's Costa del Sol. Tourist Studies 3 (3), pp. 301-317.

Oakes, T. (1999). Eating the food of the ancestors: place, tradition and tourism in a Chinese frontier river town. Ecumene 6 (2), pp. 123-145.

Obrador Pons, P. (2003). Being-on-holiday. Tourist Studies 3 (1), pp. 47-66.

Picard, M. (1996). Bali: cultural tourism and touristic culture. Singapore: Archipelago Press.

Pine, B. J., and Gilmore, J. (1999). The experience economy: work is theatre and every business a stage. Boston, MA: Harvard Business School Press. 
Potter, R. B. (2005). 'Young, gifted and back': second generation transnational return migrants to the Caribbean. Progress in Development Studies 5 (3), pp. 213-236.

Potter, R., et al. (1999). Geographies of development. Harlow, UK: Longman.

Quinn, B. (2007). Performing tourism: Venetian residents in focus. Annals of Tourism Research 34 (2), pp. 458-476.

Richards, G., and Wilson, J. (eds) (2004). The Global Nomad: backpacker travel in theory and practice. Clevedon, UK: Channel View.

Robinson, M., and Phipps, A. (2003). Worlds passing by: journeys of culture and cultural journeys. Journal of Tourism and Cultural Change 1 (1), pp. 1-10.

Ryan, C., and Hall, C. M. (2001). Sex tourism: marginal people and liminalities. London: Routledge.

Saarinen, J. (2004). 'Destinations in change': the transformation process of tourist. Tourist Studies 4 (2), pp. 161-179.

Saldanha, A. (2002). Identity, spatiality and post-colonial resistance: geographies of the tourism critique in Goa. Current Issues in Tourism 5 (2), pp. 94-111.

Schmitt, B. (1999). Experiential marketing: how to get customers to sense, feel, think, act and relate to your company and brands. New York: The Free Press.

Sheller, M., and Urry, J. (eds) (2004). Tourism mobilities: places to play, places in play. London: Routledge.

- (2006). The new mobilities paradigm. Environment and Planning A 38 (2), pp. 207-226.

Sherlock, K. (2001). Revisiting the concept of hosts and guests. Tourist Studies 1 (3), pp. 271-295.

Smith, V. (ed.) (1977). Hosts and guests: the anthropology of tourism. Philadelphia, PA: University of Pennsylvania Press.

Sparke, M. (2006). A neoliberal nexus: economy, security and the biopolitics of citizenship on the border. Political Geography 25, pp. 151-180.

Tesfahuney, M. (1998). Mobility, racism and geopolitics. Political Geography 17 (5), pp. 499-515.

Timothy, D. (2001). Tourism and political boundaries. London: Routledge.

Timothy, D., and Boyd, S. (2006). Heritage tourism in the 21st century: valued traditions and new perspectives. Journal of Heritage Tourism 1 (1), pp. 1-16.

Tolia-Kelly, D. (2004). Materializing post-colonial geographies: examining the textual landscapes of migration in the South Asian home. Geoforum 35, pp. 675-688.

Tzanelli, R. (2006). Reel western fantasies: portrait of a tourist imagination in the beach (2000). Mobilities 1 (1), pp. 121-142.

- (2007). The cinematic tourist. London: Routledge.

Verstraete, G. (2004). Technological frontiers and the politics of mobility in the European Union. In: Ahmed, S., et al. (eds) Uprootings/regroundings: questions of home and migration. London: Berg, pp. 225-250.

Wang, N. (1999). Rethinking authenticity in tourism experience. Annals of Tourism Research 26 (2), pp. 349-370.

Warren, C. (1998). Tanah Lot: the cultural and environmental politics of resort development in Bali. In: Hirsch, P. and Warren, C. (eds) The politics of environment in Southeast Asia. London: Routledge, pp. 229-259.

White, N. R., and White, P. B. (2007). Home and away: tourists in a connected world. Annals of Tourism Research 34 (1), pp. 88-104.

Williams, A., and Hall, C. M. (2002). Tourism, migration, circulation and mobility: the contingencies of time and place. In: Hall, C. M. and Williams, A. (eds) Tourism and migration: new relationships between production and consumption. Dordrecht, The Netherlands: Kluwer, pp. 5-27.

Worthington, B., and Sedakat, P. (2005). Kaliningrad - the last piece in the Baltic jigsaw? International Journal of Tourism Research 7 (2), pp. 123-134. 